\title{
Stop Motion Animation as a Learning Media to Write a Short Story
}

\author{
Alvika Candra Puspita ${ }^{1}$, St Y Slamet ${ }^{2}$, and Sumarwati ${ }^{3}$ \\ $\left\{\right.$ alvikacandra@student.uns.ac.id ${ }^{1}$ \} \\ 1,2,3 Universitas Sebelas Maret, Indonesia
}

\begin{abstract}
Numerous researches related to stop motion animation as a learning media to compose a short story needs to be developed because writing skill cannot be separated from everyday life, especially language learning in school. This study aims to investigate the factors that influence the students' writing ability in composing a short story, the perceptions about the use of stop motion animation, and the methods that were appropriate to the use of stop-motion animation as a learning media. This research was a qualitative study with a case study approach. The data collection technique used was in-depth interviews with several students and teachers as well as classroom observations. The results revealed that there were some issues encountered by the students in writing a short story, namely the students met some difficulties in expressing their thoughts and developing them into a short story and the students' limitation of vocabularies. Teaching-learning process using the Contextual Teaching and Learning (CTL) method accompanied by stop motion animation as a media gained the students' optimal learning to write a short story. Stop motion animation made the students joined the class enthusiastically.
\end{abstract}

Keywords: animation, stop motion, learning media, writing, short story, Contextual Teaching and Learning (CTL).

\section{INTRODUCTION}

Writing is an aspect of language and literary skills that plays an important role in daily life. Writing skill is one of the language skills besides reading, listening, and speaking which are practiced in Indonesian language learning. Writing can help to explore thoughts and feelings. Writing skill is not just the ability to write graphic symbols but instead deliver thoughts into written language through sentences that are arranged in full, complete, and clear so that the thoughts can be communicated to the reader successfully [1].

One of the ways to improve writing skill is through literary learning at school. One of the literary writing activities in the high school level is writing a short story. In the 2013 Curriculum, there is a Basic Competence 4.9 which is constructing a short story with the attention to the short story builder elements. In this Basic Competence, the students are required to be able to improve the creative process in connecting ideas and thoughts and developing their imagination into writing in the form of a short story. Therefore, the students' writing skill needs to be developed in order to compose good a short story. A short story is one type of literature in the 
form of prose that is different from other types of prose [2]. Most writers, editors, and publishers categorize a short story as works of fiction consisting of several thousand words, but generally no more than 5,000 [3].

Writing in general and creatively, including a short story, can be developed with the spirit of the environment in which the students are involved in the writing process [4]. The thing that needs to be done to support success in learning to write a short story is that the teacher as a facilitator should have creative and innovative teaching readiness. One of the media that can support teaching and learning activities, especially in learning to write a short story of the students is by using a learning media. Learning media is a tool that can be used for learning purposes to be achieved. Every learning media used has unique characteristics, so it needs planning in using media in learning wisely [5].

A learning media that can be used by the students to write a short story is using stop motion animation. An animation is a form of an object that changes from its original form to another form, then changes again to the shape of another object, and so on. These form changes make everyone who sees believe that the object is not dead (silent) again. This form of change psychologically creates motion, which means there is something power stored in it [6]. Stop motion can be used for any animation because the basic process is the same namely something is manipulated, moved gradually, and taken pictures. The objects taken can be dolls, pencil drawings, piles of sand, clay, computer drawings or pieces of paper.

\section{METHOD}

This research was conducted in learning to write a short story of State High Schools in Banjarnegara Regency. The technique used was purposive sampling, which is the selection of data is suited to the research needs. This study used qualitative research with a case study approach. Qualitative research was conducted to describe and explain the perceptions of teachers and students. In this study, research was conducted with Focus Group Discussions (FGD) to develop a prototype model. Interviews and in-depth observation were used to collect the data.

\section{RESULT AND DISCUSSION}

\subsection{Stop Motion Animation in Teaching Writing a Short Story}

Based on the interviews with the students, it was shown that the skill to write a short story were one of the skills that were considered difficult by students. Students claimed to have difficulties in expressing and pouring out thoughts, imagination, and developing the storyline in writing a short story. The difficulties of the students in expressing ideas and developing them into a short story have also been encountered in previous studies [7]. These issues can be anticipated by using the right media to stimulate students' imagination.

One of the factors encountered by the students was their limitation of vocabularies. The students' lack in mastering many vocabularies was the cause of their writing of a short story could not be optimal. Previous research also uncovered that the students did not have the necessary vocabularies knowledge and skill to efficiently manipulate their vocabularies knowledge [8]. A solution that can be used as an alternative to improve vocabulary mastery is by applying a culture of literacy. By familiarizing literacy activities, students will find many new vocabularies that they have never met before. This can help the students in writing a short story.

The thing that needs to be considered in teaching writing a short story was a learning media that can stimulate the students to find and maximize their ideas so as to produce well a short 
story. If the students were not given a stimulant in a form or description, the students were usually difficult to develop conflict, climax, or ending. The media used could be visual media such as stop motion animation. Stop motion animation is a technique of manipulating video movements from a collection of images as if the collection of images is like a moving video. The moving image is moved in a fast duration. Stop motion films can improve students' ability to express ideas and communicate with others [9].

Stop motion animation made the students in the teaching-learning process felt not bored and made it easier for the students to imagine the visual illustrations presented. Stop motion video learning media products in previous research could meet the needs of learning in composing short story texts for students [10]. However, stop motion animation cannot always be used as a medium in all learning. Stop motion animation media must be adjusted to the material and the needs of the students. Previously, it was explained that stop motion was able to be used in learning with appropriate materials [11]. The stop motion animation was designed to provide illustrations on the materials so the teaching-learning process was not monotonous and more interesting, especially material related to the flow of events. The use of digital devices and visual media such as stop motion animation allowed the students to explore and question their work processes and products. The existence of stop motion animation could provide opportunities for the teachers and the students to imagine and develop their thoughts.

Stop motion animation could also be used as learning media in the industrial era 4.0 as it is today. The use of tablets and stop motion animation were used to develop creativity, different thinking, and connections with the science of teaching [12]. The students could use this media to write a short story independently without any meeting or face to face in class. This was supported by previous research that explained the created learning media could be used to help in learning outside of the classroom or as teaching materials independently [13].

Nowadays, not only the students but also the teachers are required to think critically and creatively. The existence of stop motion animation could indeed help the students' writing skill in composing a short story. On the other hand, the teacher also had a problem in making stop motion animation as a learning media. The teacher perceived that making stop motion animation needed a long time. This was because each background or each shift in an object must be photographed one by one or gradually to produce an object that seems to move. Moreover, in making stop motion animation it is needed to use other tools such as paper, dolls, cameras, computers, and so on. Therefore, in making stop motion animation it is important for the teachers to master Information and Technology (IT). Unfortunately, not all teachers want and are able to learn in depth. Providing new media can be an attraction for the students rather than forcing conservative learning methods with conventional media. The existence problems above can be overcome by increasing the teachers' resources to practice and deepen IT knowledge hence they are able to produce creative and innovative media in the digital era.

\subsection{Applying Stop Motion Animation with Contextual Teaching and Learning (CTL) method}

Besides the learning media, the method used by the teachers is also very important and is one of the factors that influence the learning process. The existence of media and methods that synergize appropriately make learning material well and efficiently delivered. After conducting discussions with several Indonesian language teachers in Banjarnegara Regency, the appropriate method to be applied with stop motion animation was the Contextual Teaching and Learning (CTL) method. Learning methods Contextual Teaching and Learning (CTL) is a holistic learning process and aims to help the students to understand the meaning of teaching material and relate it to the context of their daily lives (personal, social and cultural context), thus the 
students have dynamic knowledge/skills and flexible to actively construct by themselves [14]. Previous research shows that contextual learning has a more significant influence than noncontextual learning groups in writing skill [15].

Contextual Teaching and Learning (CTL) method could be applied with stop motion animation to practice students' short story writing skill because the base of a short story is about a small part of a person's life. This is in line with the characteristic of the Contextual Teaching and Learning (CTL) method, which is to link learning material with the real life of the students. The students are encouraged to make connections between the knowledge they have and their application in everyday life.

Teaching-learning process to write a short story using stop motion animation with the Contextual Teaching and Learning (CTL) method can be done in a few steps. The first step is for the teacher to deliver material about short story building elements; the teacher divides the students into several groups; the teacher shows the stop motion animation video in front of the class; the students in groups individually observe the stop motion animated videos that have been aired; the students dig information by asking the teacher about the presentation in stop motion animation videos; the students receive reinforcement from the teacher about stop motion animated videos that have been aired; the students write a short story based on presentation in stop- motion animation; the students associate the contents of a short story with real life; the students present the results of writing a short story in front of the class.

Stop motion animation is presented with the topics commonly found in the students' daily lives such as environment, social, nature, culture and so on. Furthermore, the students understand what learning means, what the benefits of learning are, in what status they are in, and how to achieve it [16]. Students will realize that what they learn will benefit their lives. Stop motion animation is presented without writing with the aim of giving stimulus to the students so that they can develop their imagination and the creative process of literature occurs in writing a short story. Thus, stop motion animation will be more effectively used in learning to write a short story in terms of drawing elements of the story according to the video presented in the stop- motion animation [17].

\section{CONCLUSION}

Based on the results, it was found that the students met some issues in writing a short story. The students found it was difficult to develop the storyline in writing it. Thus, the students' limitation of vocabularies also led them to felt difficult in writing a short story. By using stop motion animation as a learning media, the students perceived that it helped them to imagine and develop the storyline in writing a short story with visual illustrations presented. This learning media could also be used by students to practice in writing a short story independently without any meeting in class. In another hand, it was found that the teacher faced the difficulties in making the learning media. This issue can be solved by increasing the teacher's awareness of the importance of mastering the technology to create digital media. Stop motion animation as a learning media can be optimized with the Contextual Teaching and Learning (CTL) method because the concepts of a short story are in line with the characteristics of the CTL method.

\section{REFERENCES}

[1] K. Saddhono and S. Y. Slamet, Pembelajaran Keterampilan Berbahasa Indonesia: Teori dan Aplikasi. Yogyakarta: Graha Ilmu, 2014.

[2] R. Wellek and A. Warren, Teori Kesusastraan. Jakarta: Gramedia, 2014. 
[3] W. Brut-Thomas, The Everything Creative Writing Book: All you need to know to write novels, plays, short stories, screenplays, poems, articles, or blogs, 2nd ed. U.S.A.: Adams Media, 2010.

[4] S. Saleh Khalaf Ibnian, "The Effect of Using the Story- Mapping Technique on Developing Tenth Grade Students' Short Story Writing Skills in EFL," English Lang. Teach., vol. 3, no. 4, pp. 181-194, 2014.

[5] S. Adi Widodo, "Selection of Learning Media Mathematics for Junior School Students," TOJET Turkish Online J. Educ. Technol., vol. 17, no. 1, pp. 154-160, 2018.

[6] G. Prakosa, Animasi: Pengetahuan Dasar Film Animasi Indonesia. Jakarta: Nalar, 2010.

[7] E. Rochaeni, "Peningkatan Keterampilan Menulis Cerita Pendek dengan Menggunakan Media Planned Humor KakaoTalk," J. Lingk. Widyaiswara, vol. 2, no. 2, pp. 1-15, 2015.

[8] A. Ashrafzadeh and V. Nimehchisalem, "Vocabulary Knowledge: Malaysian Tertiary Level Learners' Major Problem in Summary Writing,” J. Lang. Teach. Res., vol. 6, no. 2, p. 286, 2015.

[9] K. T. Sun, C. H. Wang, and M. C. Liku, "Stop-motion to foster digital literacy in elementary school," Comunicar, vol. 25, no. 51, pp. 93-102, 2017.

[10] Fakhri Ali Azizi and M. Doyin, "Jurnal Pendidikan Bahasa dan Sastra Indonesia,” J. Pendidik. Bhs. dan Sastra Indones., vol. 5, no. 2, pp. 44-59, 2016.

[11] D. F. R. Putri and U. Zuhdi, "Pengaruh Penggunaan Media Stop Motion terhadap Hasil Belajar IPS Materi Detik-Detik Proklamasi Siswa Kelas V SDN Gadingmangu 1 Jombang," J. Penelit. Pendidik. Guru Sekol. Dasar, vol. 6, no. 12, pp. 2316-2325, 2018.

[12] W. I. O’Byrne, N. Radakovic, T. Hunter-Doniger, M. Fox, R. Kern, and S. Parnell, "Designing Spaces for Creativity and Divergent Thinking: Pre-Service Teachers Creating Stop Motion Animation on Tablets," Int. J. Educ. Math. Sci. Technol., vol. 6, no. 2, pp. 182-199, 2018

[13] S. Maryanti and D. T. Kurniawan, "Pengembangan Media Pembelajaran Video Animasi Stop Motion Untuk Pembelajaran Biologi Dengan Aplikasi Picpac," J. BIOEDUIN Progr. Stud. Pendidik. Biol., vol. 8, no. 1, pp. 26-33, 2018.

[14] M. Idrus Hasibuan, "Model Pembelajaran CTL (Contextual Teaching and Learning)," Logaritma, vol. II, no. 1, pp. 1-12, 2014.

[15] A. Hasani, "Enhancing Argumentative Writing Skill through Contextual Teaching and Learning," Educ. Res. Rev., vol. 11, no. 16, pp. 1573-1578, 2016.

[16] H. Lotulung, Chrisant Florence., Ibrahim, Nurdin., \& Tumurang, "Effectiveness of Learning Method Contextual Teaching Learning (CTL) for Increasing Learning Outcomes of Entrepreneurship Education," TOJET - Turkish Online J. Educ. Technol., vol. 17, no. 3, pp. 37-46, 2018.

[17] K. Saddhono and M. Rohmadi, "A Sociolinguistics Study on the Use of the Javanese Language in the Learning Process in Primary Schools in Surakarta, Central Java, Indonesia." Int. Edu. Stu., vol. 7 no.6 pp 25-30, 2014 